\title{
Chrysippus on Retribution and Rehabilitation
}

\author{
Paulo Ferreira \\ pauloferreira81@gmail.com \\ Universidade Federal de São Paulo (UNIFESP), Guarulhos, Brasil
}

resumo Este artigo argumenta que a resposta de Crisipo à objeção segundo a qual o Destino é incompatível com o fato de algo estar em nosso poder (e, portanto, com a justiça de honras e punições) consiste em uma correção daquilo que se entende por estar em nosso poder (de uma noção em termos de originação última para uma noção em termos de causação autossuficiente) e, pois, em uma correção igualmente daquilo que se entende por justiça em honras e punições (de uma noção em termos retributivos para uma noção em termos reabilitativos).

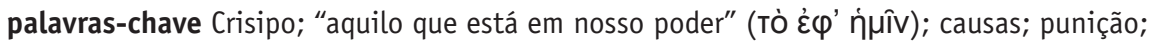
retribuição; reabilitação

My aim in this paper is to discuss Chrysippus' reply to the objection that Fate does away with justice in honor and punishments in Cicero, Fat. 413. In particular, I want to stress that Chrysippus' reply involves a shift from retributive to rehabilitative justice, visible on the different meanings assigned to the Latin esse (situ) in nobis/esse in nostra potestate (correspondent to the

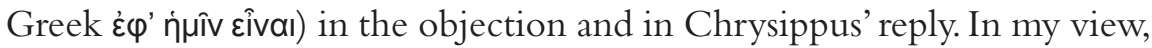
the discussion reported by Cicero concerning "that which is up to us" and justice in honor and punishments is continuous with, and complements,

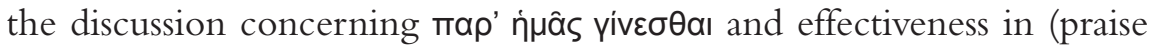
and blame qua) exhortations reported by Diogenianus (apud Eusebius, Praep. Ev.VI 8). I begin with a few words on the latter. ${ }^{2}$ 
In Eusebius, Praep.Ev.VI 8 1-2 and 25, Diogenianus reports that Chrysippus, in Book I of his work On Fate, attempted to show that everything is

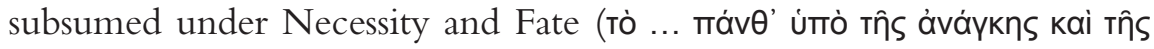

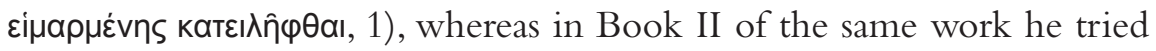
to solve the many absurdities that are taken to follow from that thesis and establish that many things also depend on us (тò kaì пар' ñuâs по 2). ${ }^{3}$ A close inspection of Diogenianus' testimony in sections 26-38 shows that two strata should there be distinguished: Chrysippus' reply (from Book II of his work On Fate) to an objection leveled against his theory of Fate (in sections 26-9 and parts of sections 33-4, clearly demarcated by the use of $\varphi$ riv, "he [=Chrysippus] says"), and Diogenianus' own (further) objection to Chrysippus' reply to the original objection (in the remaining portions of sections 26-38: cf. oînaıı, "I [=Diogenianus] think," 30; हїтоı' äv, "I [=Diogenianus] would say," 33).

The original objection addressed by Chrysippus in the testimony is never explicitly formulated in the text. All we have is a statement to the effect that from the fact that everything takes place according to Fate it supposedly follows "the suppression ... of the eagerness that proceeds from our own selves and concerns praise, blame, and exhortation, and of everything that manifestly depends on our causation for its taking

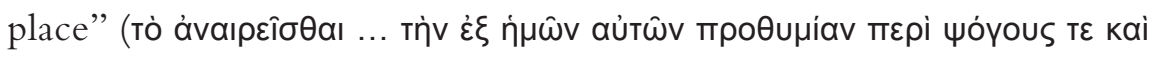

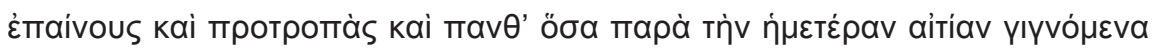
paívetaı, 25).

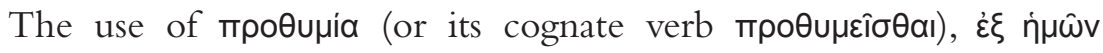

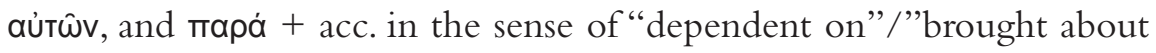
by" in connection with the issue of exhortation (протротиं) seems to me reminiscent of the digression in Book XXV of Epicurus' work On Nature (esp. LS 20C10-11), where it is stated that Epicurus' opponent

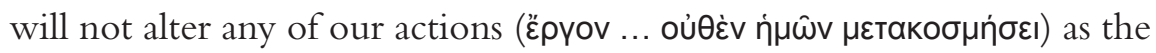

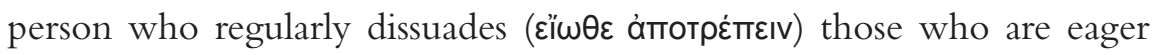

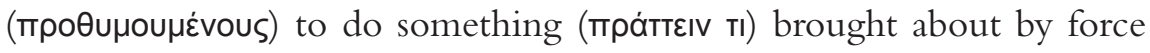

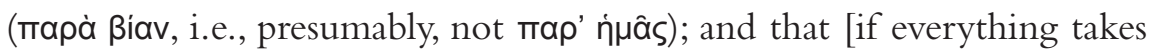
place by Fate] one will inquire what sort of action proceeds somehow

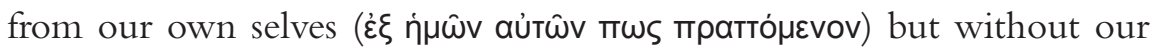




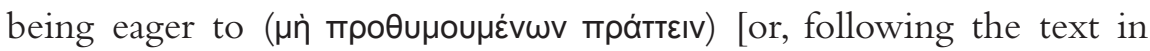

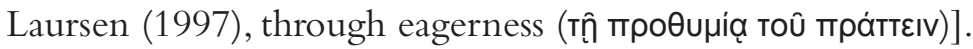

As for the second part of the passage, either (following Sedley's text) it makes no sense to say of a class of fated actions that they proceed somehow from our own selves but without our being eager to because the same would be true of all fated actions, or (following Laursen's text) there is no fated action such that it proceeds somehow from our own selves through eagerness; either way, Epicurus may be here read as asserting that Fate

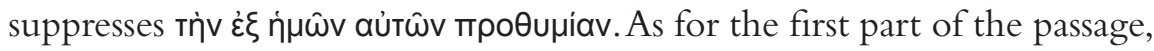
since (allegedly) nothing takes place пар' ñuâs but everything takes place mapà ßiav if everything takes place by Fate, there is no point in trying to dissuade one from doing something and in trying to alter one's action.

More explicitly, a little earlier on in the digression (LS 20C2) the

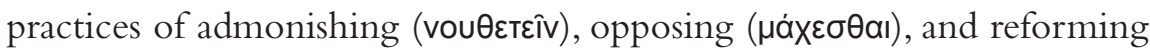
( again, Epicurus may be here read as asserting that Fate would render us incapable of making a difference as regards future courses of events: all our efforts would be pointless and futile given the fixity of what shall come to pass.

That, of course, is false. To say that an event is fated is not to say that it will take place regardless and that we do not have a hand in making it the case. Nevertheless, Epicurus' text does allow for such reading, ${ }^{4}$ which would in turn entail that there is no point in admonishing, opposing, attempting to reform or even dissuade a person from a given course of actionapparently, the same idea behind the original objection against Chrysippus' theory of Fate in Diogenianus, i.e. that genuine openness is required in order for praise and blame to play an effective role as exhortations.

Chrysippus is therefore certainly right in claiming that an outcome's being fated along with our decisions and actions (i.e. its being fated only if our decisions and actions are themselves fated to take place as well) is sufficient for such outcome to proceed from us in the relevant sense

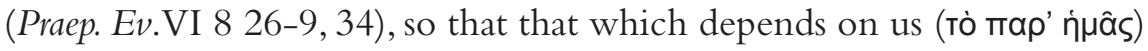
is after all subsumed under Fate (33): if one's decisions and actions are effective in influencing the course of events and in bringing about a given outcome, then it makes sense to (praise or blame a person in order to) exhort her to produce that outcome. 
One may claim, however, that while under Fate praise and blame do have a point as exhortations, they are nevertheless not deserved by the agents, since that requires ultimate origination, i.e. the fact that we author our decisions and actions, which in turn requires that they be insufficiently caused by previous events outside our control, so as to assure us genuine openness to decide and act thus or otherwise.

Chrysippus must then attempt to prove that determinism is compatible with justice in honor and punishments-his task being all the more pressing since the incompatibilist might still claim that on her analysis both effectiveness in (praise and blame qua) exhortations and justice in honor and punishments are accounted for. In fact, while it is false to say that the fact that a misfortune shall take place unless we guard ourselves against it entails that it is up to us ('̇ं 'ं nîv) to guard or not to guard ourselves against it (as Diogenianus claims in Eusebius, Praep. Ev. IV 3 10), the incompatibilist might still (correctly) claim that the same openness that guarantees the latter also guarantees the former-which is exactly what one finds in Sextus, $M \mathrm{~V}$ 46-8 (a passage of possible Epicurean

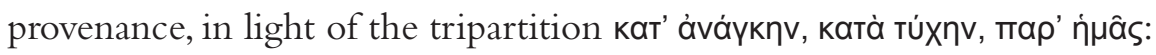
cf. DL X 133), where it is sufficient for an event to take place пар' ṅâs that it be "that whose taking place or not is up to me, i.e. that which does

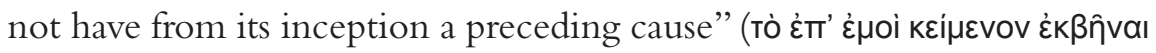

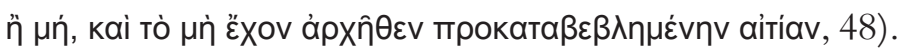

This difficulty (and Chrysippus' reply) is what one finds in Cicero, Fat. 40-3. There, the objection addressed by Chrysippus sets out to show that, if everything takes place by Fate, then we are not the ultimate origin or first cause of our assents and actions, which has in turn the consequence that our assents and actions are not up to us, so that praise and blame, as well as honor and punishment, for them are not deserved.

\section{II}

Two strata should be distinguished in Cicero, Fat. 39-45: one composed of (what appears to be) translated quotations and paraphrases, containing both the original objection and Chrysippus' reply (fully reproduced in what follows); the other consisting of a third-party assessment of the 
debate, concerned with the issue of modality, and corresponding to $\$ \$ 39$ and $44-5$, along with a few sentences in the respective openings of $\$ \$ 40$, 41 , and 42 (omitted below). The connection between Fate and necessity is explicitly made only in the (apparently later) framework, not in the original objection and reply - in fact, if my reading of $\$ \int 40-3$ (as well as of $\$ \int 7-11$ : below, IV (i)) is correct, it is not even required at this juncture. I therefore disagree with Bobzien (1998a: 255-6) when she says that what is under attack in the objection is the claim that our assents' being fated does not entail their being necessary. Instead, I think the original objection is primarily concerned with Fate's precluding ultimate origination, while the (alleged) incompatibility between Fate and our actions' not being necessary constitutes a different objection-of which Plutarch, St. Rep. 46 may also be regarded as a testimony.

The original objection is presented as follows:

"Si omnia fato fiunt, omnia fiunt causa antecedente, et, si adpetitus, illa etiam, quae adpetitum sequuntur, ergo etiam adsensiones; at, si causa adpetitus non est sita in nobis, ne ipse quidem adpetitus est in nostra potestate; quod si ita est, ne illa quidem, quae adpetitu efficiuntur, sunt sita in nobis; non sunt igitur neque adsensiones neque actiones in nostra potestate. Ex quo efficitur, ut nec laudationes iustae sint nec vituperationes nec honores nec supplicia." Quod cum vitiosum sit, probabiliter concludi putant non omnia fato fieri, quaecumque fiant. "If all things come about by fate, all things come about by an antecedent cause; and if impulses do, so too do those things which follow on impulse; and therefore so too do assentings. But if the cause of impulse is not up to us, impulse itself too is not in our power; and if this is so, neither are those things which are brought about by impulse up to us. So neither assentings nor actions are in our power; and from this it follows that neither praise nor blame nor honors nor punishments are just." But since this is wrong, they think that the conclusion can reasonably be drawn that it is not the case that all things that come about do so by fate [Fat. 40; trans. Sharples, slightly altered].

Before we proceed, two issues must be clarified. First, the Latin phrases esse (situ) in nobis ("to be up to us") and esse in nostra potestate ("to be in our power") are used interchangeably in the passage, and seem to correspond 


\section{4}

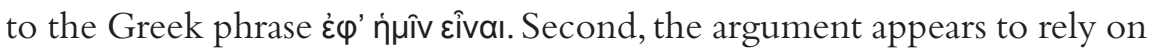
Stoic psychology of action as exposed, e.g., in Seneca, Ep. 113 18:

Omne rationale animal nihil agit nisi primum specie alicuius rei inritatum est, deinde impetum cepit, deinde adsensio confirmavit hunc impetum.

Every rational animal remains inactive unless it is first stirred by the impression of something; then comes impulse; then assent confirms that impulse.

Cicero's adpetitus appears thus to correspond to Seneca's impetus, and to stand for unconfirmed impulse. (Or, alternatively, Cicero's adpetitus may stand for the (impulsive) impression itself, which would then be followed by assent; either way, what is here termed "impulse" non-standardly precedes rather than follows assent.)

Matters being such, let us now turn to the argument. The first assumption is,

[1] If everything takes place by Fate, then everything takes place by an antecedent cause (si omnia fato fiunt, omnia fiunt causa antecedente),

which follows from Stoic view on Fate as the chain of causes. The second assumption is never enunciated in general terms in Cicero's report, but may be formulated as follows on the basis of its two instantiations in the sequence (namely, "If the cause of 'impulse' is not up to us, then neither is 'impulse' itself in our power," si causa adpetitus non est sita in nobis, ne ipse quidem adpetitus est in nostra potestate; and "If this is so [i.e., if 'impulse' itself is not in our power], then neither are those things up to us which are caused by "impulse,", quod si ita est, ne illa quidem, quae adpetitu efficiuntur, sunt sita in nobis):

$<$ [2] If the cause of $\mathrm{x}$ is not in our power, then $\mathrm{x}$ is not in our power either.>

For something to be up to us is, I think, here to be understood in terms of our being its ultimate origin or first cause (see above, p.6 on Sextus, MV 48), which then explains the stress on anteceding causes in the argument. This being so, it should be clear that the consequent in $[1]^{5}$ entails the antecedent in [2]. 
Two further assumptions are needed:

$<$ [3] If our assents and actions are not in our power, then praise and

blame, as well as honor and punishment, [for them] are not just,>

and

$<$ [4] Praise and blame, as well as honor and punishment, are just.>

These may easily be gathered from the text, but are never presented in so many words. Since, then, the antecedent in [3] is but an instantiation of the consequent in [2], it follows, on the basis of the assumptions, that it is not the case that everything takes place by Fate. ${ }^{6}$

The central step is to understand something's being up to us in terms of ultimate origination. Correspondingly, Chrysippus' reply consists in a distinction between types of causes (or, rather, between schemes of causation) according to which [2] is not valid for preceding causes, only for self-sufficient ones:

"Causarum enim," inquit, "aliae sunt perfectae et principales, aliae adiuvantes et proximae. Quam ob rem, cum dicimus omnia fato fieri causis antecedentibus, non hoc intellegi volumus: causis perfectis et principalibus, sed causis adiuvantibus [antecedentibus] et proximis." Itaque illi rationi, quam paulo ante conclusi, sic occurrit: si omnia fato fiant, sequi illud quidem, ut omnia causis fiant antepositis, verum non principalibus causis et perfectis, sed adiuvantibus et proximis. Quae si ipsae non sunt in nostra potestate, non sequitur, ut ne adpetitus quidem sit in nostra potestate. At hoc sequeretur, si omnia perfectis et principalibus causis fieri diceremus, ut, cum eae causae non essent in nostra potestate, ne ille quidem esset in nostra potestate. "For," he said, "some causes are perfect and primary, others auxiliary and proximate; and for this reason, when we say that everything comes about by fate through antecedent causes, we do not want this to be understood as 'through perfect and primary causes,' but as 'through auxiliary and proximate causes." And so he meets the argument, which I set out a short while ago, as follows. If all things come about by fate, it does indeed follow that all things come about by causes that precede them, but these are not perfect and primary causes, rather auxiliary and proximate ones. And if those themselves are not in our power, it does 
not follow that impulse too is not in our power. This would follow, if we said that all things come about through perfect and primary causes, so that, since those causes are not in our power, impulse too would not be in our power [Fat. 41; trans. Sharples].

Chrysippus distinguishes between auxiliary/proximate causes and perfect/primary ones. As we shall see (below, p.15), perfect/primary causes by themselves suffice for the outcome, so that (as the sources remark: cf. Sextus, M IX 238 and 242; Clement, Strom. VIII 9 33.1) they are completely simultaneous with the result: the outcome ensues whenever, and only whenever, its perfect/primary cause is present.

The distinction is then applied to assumptions [1] and [2] of the argument. Assumption [1] deals with Fate insofar as it is conceived as a chain of preceding causes; therefore, it cannot be valid for perfect/ primary causes, only for non-perfect/primary ones. Assumption [2], on the other hand, does not necessarily deal with preceding causes; as we have seen (above, p.9), it is the opponent's contention that it does, but that contention is now called into question by Chrysippus.

I take it is Chrysippus'view that it cannot be the case that what it means for something to be up to us is for us to be its ultimate origin or first cause. For him, accepting that, together with assumption [3] in the argument (which is never called into question), would have the consequence that praise, blame, honor, and punishment can only be just if we, rather than anything else, are the authors of that for which we are praised, blamed, honored, or punished - presumably because only thus one may, say, inflict a (justified and legitimate) injury on another on account of an offense. In Stoic terms, however, that would amount to no more than paying back a (dispreferred) indifferent for another, and would therefore completely miss the point of what it is for punishments to be just.

Cicero paraphrases Chrysippus as claiming that it is a necessary condition for "impulse" itself to be in our power that the perfect/primary causes of "impulse" be in our power ("Since those causes are not in our power, impulse too would not be in our power," cum eae causae non essent in nostra potestate, ne ille quidem esset in nostra potestate). In my view, that should be read not only as a statement to the effect that no antecedent causes of our "impulses" may be their perfect/primary causes if we are to 
be responsible for them—as Bobzien (1998a:255-8 and 1998b) reads itbut also as a statement to the effect that we must be the perfect/primary causes of our "impulses" if we are to be responsible for them.

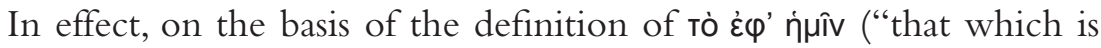

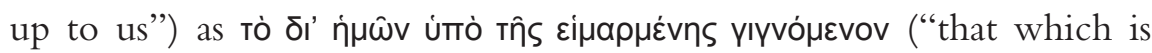
subsumed under Fate and takes place on our account") in Alexander, Fat. 13-4 (cf. the second hand in MS B [Marcianus gr. 261] at 181.14 with 182.3-4, 7-8, 12-13, and 182.31-183.3) and Nemesius, Nat. Hom. 35, I surmise that Chrysippus reformulates assumption [2] in the argument as

$\left[2^{\star}\right]$ If our nature is not $x$ 's perfect/primary cause, then $\mathrm{x}$ is not up to us.

Hahm (1994) has convincingly shown that סid + gen. is used in Stoicism to refer to outcomes brought about through an item's nature (including the nature of inanimate items such as a stone or, one may add, cylinders and cones).That, in turn, explains the use of the phrase in Clement, Strom. VIII 925.3 and 33.2, where the sustaining cause (бUvعктікòv aïtıov) is

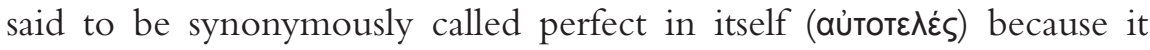
"self-sufficiently, on its own account produces its outcome" (аủтáркws

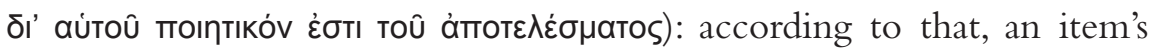
nature or sustaining cause may be said to bring about on its own account outcomes such as a stone's falling down when released from a certain height. Since, in addition, such cause is synonymously called perfect in itself, the definiens in Alexander and Nemesius ("that which is subsumed under Fate and takes place on our account") may be understood as "that which is subsumed under Fate and has our nature as the perfect/primary cause of its taking place"-which in turn entails [2*].

Bobzien (1998a: 359-70) argues that the definition in Alexander and Nemesius should be ascribed not to Chrysippus but only to Philopator (2nd century AD): while "the Stoics Chrysippus, Philopator, and many

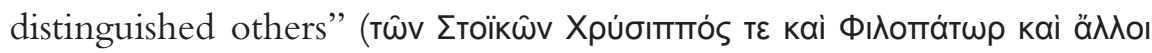

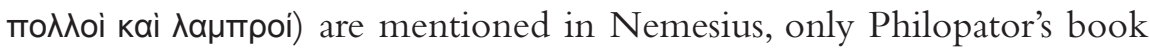
On Fate is alluded to in the immediate context from which the definition is extracted. But, as we have seen, Diogenianus's report on Book II of Chrysippus' work On Fate (apud Eusebius, Praep. Ev.VI 8) allows for the ascription of a remarkably parallel definition of tò map' ṅuâs ("that which

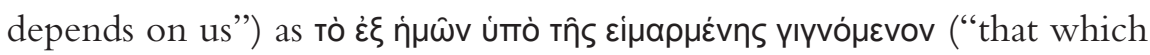


is subsumed under Fate and whose taking place proceeds from us") to Chrysippus. ${ }^{7}$ That might point in the direction of a Chrysippean strategy of amending notions of the debate on Fate and moral responsibility so as to fit his own views, and would increase the likelihood of ascribing also to Chrysippus the definition reported by Alexander and Nemesius.

Matters being such, we are now faced with the issue of clarifying what it means for something to be a perfect/primary cause and how that relates to the issue of justice in praise, blame, honor, and punishment. Let us begin with the cylinder and cone analogy, presented in the sequence in Cicero's text:

Quod enim dicantur adsensiones fieri causis antepositis, id quale sit, facile a se explicari putat. Nam quamquam adsensio non possit fieri nisi commota viso, tamen, cum id visum proximam causam habeat, non principalem, hanc habet rationem, ut Chrysippus vult, quam dudum diximus, non ut illa quidem fieri possit nulla vi extrinsecus excitata (necesse est enim adsensionem viso commoveri), sed revertitur ad cylindrum et ad turbinem suum, quae moveri incipere nisi pulsa non possunt. Id autem cum accidit, suapte natura, quod superest, et cylindrum volvi et versari turbinem putat. "Ut igitur," inquit, "qui protrusit cylindrum, dedit ei principium motionis, volubilitatem autem non dedit, sic visum obiectum inprimet illud quidem et quasi signabit in animo suam speciem, sed adsensio nostra erit in potestate, eaque, quem ad modum in cylindro dictum est, extrinsecus pulsa, quod reliquum est, suapte vi et natura movebitur. Quodsi aliqua res efficeretur sine causa antecedente, falsum esset omnia fato fieri; sin omnibus, quaecumque fiunt, veri simile est causam antecedere, quid adferri poterit, cur non omnia fato fieri fatendum sit? modo intellegatur, quae sit causarum distinctio ac dissimilitudo."

As for the statement that assentings come about through causes laid down beforehand, [Chrysippus] thinks that he can easily explain this. For although assenting could not occur unless aroused by a senseimpression, nevertheless, since it has this sense-impression as proximate and not as primary cause it may be explained, as Chrysippus would have it, in the way that we described some time ago; not indeed that the assenting could occur without being aroused by any external force- for it is necessary that assenting should be caused by a 
sense-impression - but he goes back to his cylinder and spinning-top; these cannot begin to move unless pushed, but, when this has happened, he thinks that for the rest it is by their own nature that the cylinder rolls and the top moves in a curve. "As therefore," he says, "he who pushes a cylinder gives it the beginning of its motion, but does not give it rollability; so a sense-impression when it strikes will, it is true, impress and as it were stamp its appearance on the mind, but assenting will be in our power, and, in the same way as was said in the case of the cylinder, it is pushed from outside but for the rest moves by its own force and nature. If something were to occur without an antecedent cause, it would not be true that everything occurred by fate; if however it seems likely that everything which happens is preceded by a cause, what reason can be adduced for not admitting that everything occurs by fate?- provided only that it is understood what is the distinction and difference among causes" [Fat. 42-3; trans. Sharples, slightly altered].

Bobzien (1998a: 258-71 and 1998b) criticizes what she calls "the standard interpretation" of the analogy-e.g., that of Frede (1980/1987) - for taking the second factor in the analogy (i.e., the nature of the cylinder, cone, or person) both as cooperating with the first factor (i.e., the push, or the impression) and as being a perfect/primary cause: in Stoic physics, a perfect/primary cause brings about its outcome wholly by itself, and does not cooperate with any other factor. Furthermore, a perfect/primary cause, being the same as a sustaining cause (see above, p.117, on Clement, Strom. VIII 925.3 and 33.2), is cause not of a movement but of a state of affairs in Stoic physics - whereas, she claims, the effect in the analogy is not a state of affairs but a movement. In her view, Chrysippus' sole aim here is to show that the second, cooperating factor in the analogy is responsible for the outcome to the following extent: since two different items, $a$ and $b$, respond differently to the same item $c$ (correspondent to the first factor in the analogy), $a$ and $b$ are thus responsible for the (moral) quality of the effect, it therefore being up to each of them to respond thus or otherwise to $c$ in the sense that each makes a different contribution to the outcome. Specifically,

Physically, the difference between individual natures of our minds are due to a difference in the tension (tóvos) of the mind-pneuma. In every 
prospective case of assent, whether the incoming impression results in an act of assent to it will depend on the state of tension of that pneuma. Thus, the individual nature of the person's mind is responsible for whether assent is given, as the shape of the pushed object is for whether it will roll ... It is the faculty of assent which makes it possible for adult human beings to become the controlling factor of their actions, in that it enables them to respond to externally induced impressions in accordance with the individual nature of their mind. They are thus not forced in their decisions and actions (1998a: 268-9).

Nevertheless, how does that show that what $a$ and $b$ do is something for which $a$ and $b$ may justly be praised, blamed, honored, or punished? Absence of external compulsion is clearly not sufficient for such result, since it is not sufficient to establish that we, and not whatever determines our natures, are the authors of our decisions and actions. ${ }^{8}$ In my view, Bobzien is right in claiming that perfect/primary causes are noncooperative, but wrong in taking the second factor in the analogy as a cooperative, non-perfect/primary cause; instead, it should be seen as a non-cooperative, perfect/primary cause-which then explains, as we shall see, why Chrysippus thinks a person may justly be praised, blamed, honored, or punished.

Sextus, $M$ IX 237-45 may illuminate a few points in the analogy. There, two schemes of causation are distinguished, one in which a cause is said to require an auxiliary (бuvepyóv) in order to bring about its outcome, the other in which a cause is said to bring about its outcome "completely

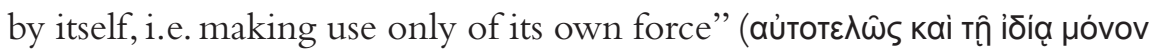

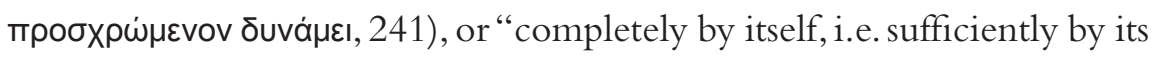

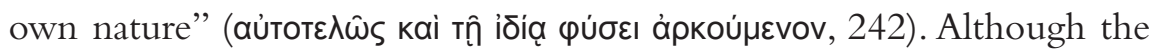
latter passage does not attribute to Chrysippus the doctrine it reports, one is here reminded of the phrases used by Cicero to characterize the way the second factor brings about its outcome in the analogy, namely, suapte natura ("by its own nature," 42) and suapte vi et natura ("by its own force and nature," 43).

Cicero, Top. 58-61 also speaks about "causes which effect $<$ their result $>$ singly, with no auxiliary" (causae quae plane efficiant nulla re adiuvante), and offers wisdom (sapientia) as an example, since it "makes $<$ the wise $>$ wise 
all by itself" (sapientis efficit sola per se). ${ }^{9}$ According to the example, one's mind thus and thus disposed (so as, say, to be wise) all by itself causes one to, say, be such as to assent to presentation $x$ and refuse assent to presentation $y$.

One must notice that such cause is said to effect not one's acting thus or otherwise but one's being thus or otherwise-which of course includes one's being such as to act thus or otherwise. The latter point may be appreciated also in the analogy, once one acknowledges that phrases such as quod superest in $\$ 42$ and quod reliquum est in $\$ 43$ ("for the rest") may be explained away as a simple misreading of the prefix of a verb such

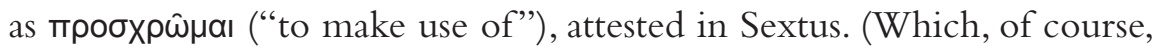

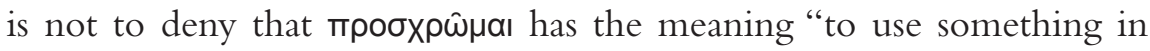
addition," only to claim that in some cases, if the prefix is not simply otiose, the verb has instead the meaning "to use something in a given connection." An example of the latter meaning may in fact be found in Sextus, MVIII 463-4, where it is said that the person who claims there is no demonstration does that either demonstrating her claim by way of an argument or "making use of a bare, undemonstrated assertion" ( $\Psi$ ıṇ̂ kai

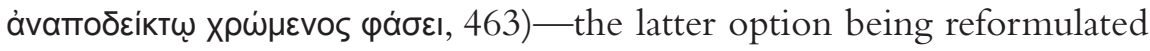
in the sequence as "making use of a bare assertion in that connection"

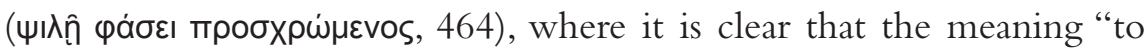
use [the bare assertion that there is no demonstration] in addition" is ruled out.) Thus, passages such as id autem cum accidit suapte natura quod superest et cylindrum volvi et versari turbinem putat $(\$ 42)$, and extrinsecus pulsa quod reliquum est suapte vi et natura movebitur (\$43) should be read, once quod superest and quod reliquum est are dropped, as "Chrysippus thinks that by their own nature the cylinder rolls-when-pushed and the cone spins-when-pushed," and "by its own force and nature it will-move-when-pushed-from-outside."

That according to Chrysippus one is (justly) praised, blamed, honored, or punished for the fact that one's nature is the perfect/primary cause of an effect such as acting-thus-when-such-and-such-obtain may be gathered also from Galen, PHP IV 6, where Chrysippus is presented as having claimed (in the Ethics [=Book IV, or the Therapeutics] of his work On Affections) that, since the tension (Tóvos) of a person's mind may

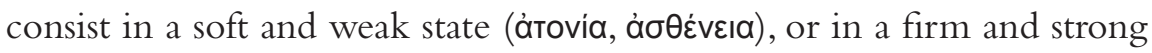




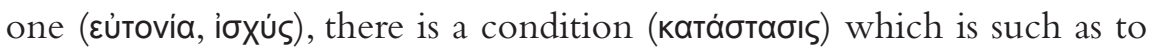

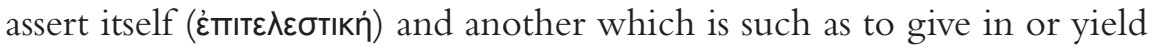
(غ̇vסоoтıкń)—namely, to the passions. Galen continues:

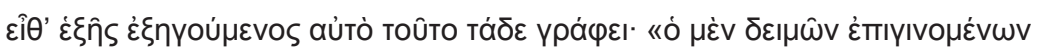
à

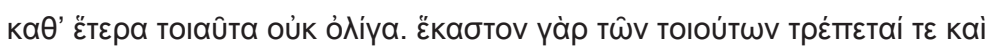

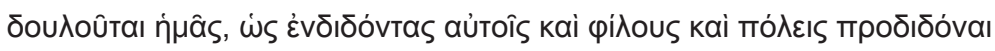

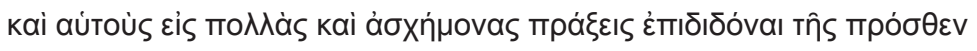

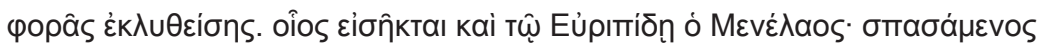

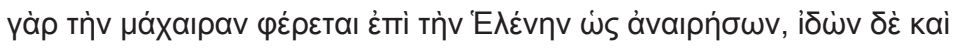

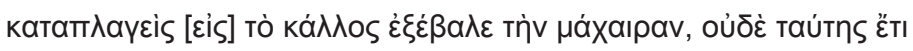

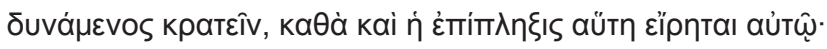

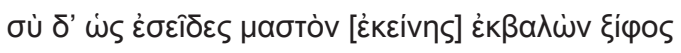

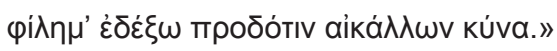

He [=Chrysippus $]$ then writes an explanation of this very statement: "One person desists when dangers arise, another yield and gave in when gain or loss were brought about, another upon encountering other such things, not few in number. Every such situation defeats and enslaves us, so that by yielding to it we betray friends and cities and offer ourselves up to many shameful acts after our former impetus has gone slack. Euripides has presented Menelaus as this kind of person. He drew his sword and rushed at Helen to kill her, but on seeing $<$ her $>$ and being struck by her beauty he let the sword drop, no longer able even to keep his hold on it. He was accordingly rebuked with these words [Andr. 629-30]:

When you caught sight of her breast you dropped your sword And took her kiss, fawning on the treacherous bitch" [PHP IV 6 7-9; trans. De Lacy, slightly altered].

The passage from Euripides is part of Peleus' long rebuke of Menelaus when the latter is on the brink of killing Andromache and her son

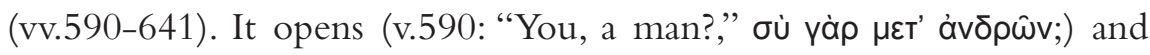

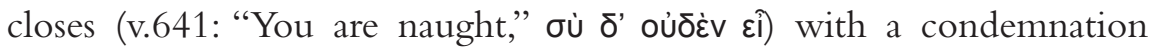
of Menelaus' whole person. Menelaus is rebuked, among other things, also for being such that he even bid Agamemnon sacrifice Iphigenia 
(vv.624-5)—“"such was your dread to lose your worthless wife," oüTws

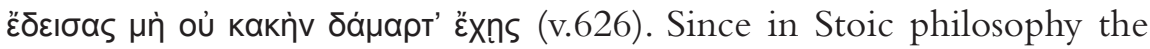
tension in one's mind-pneuma corresponds to one's mind's being thus

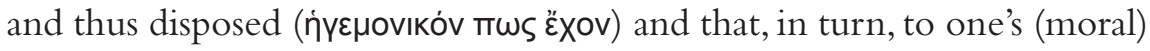
nature, one may infer that Chrysippus read Peleus' rebuke of Menelaus as aimed at Menelaus' moral nature-in view, one may add, of correcting it (the aim of the Therapeutics being after all the cure of the passions), if only in so far as would allow Andromache and her son presently not to be killed.

\section{III}

What, however, is the point of all this? As we have seen in his reply to the objection reported by Diogenianus (apud Eusebius, Praep. Ev.VI 8), Chrysippus thinks that, even though everything takes place by Fate, praise and blame are still necessary in order to effect a change in one's ways; now, faced with the objection that praise and blame, as well as honor and punishment, are not just if everything takes place by Fate, Chrysippus provides in his reply an account of "that which is up to us" in terms of self-sufficient causation ("that which has our nature as its perfect/ primary cause") which does not square with a conception of justice in retributive terms, as the objection has it, but is tailored to suit one in rehabilitative terms: praise and blame, as well as honor and punishment, are only apposite if the person stands in need of amendment-which, in turn, is in the very least compatible with (if it does not imply) her being of such nature as to act in certain ways in given circumstances.

The claim that punishment is to be understood as corrective in character in the lines sketched above may also underlie the following passage from Plutarch, St. Rep. 15:

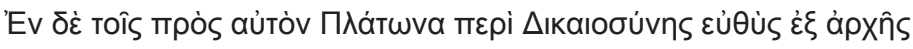

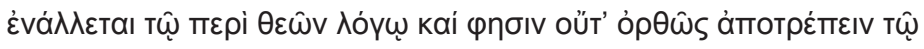

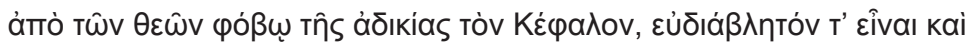

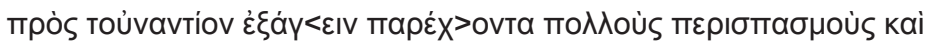

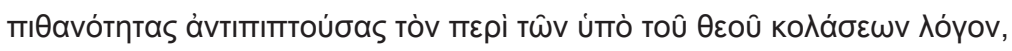

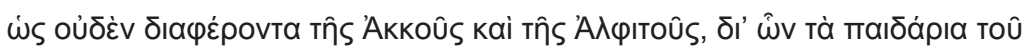


какобХо

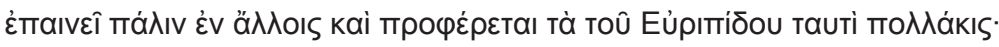

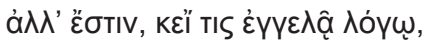

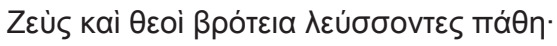

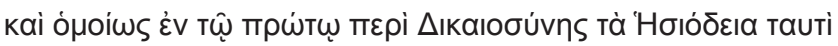

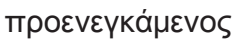

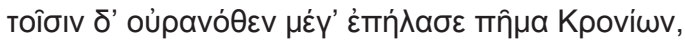

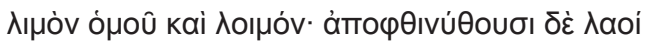

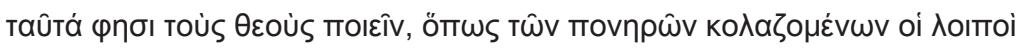

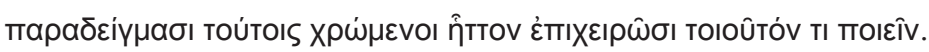
At the very beginning of the books concerning Justice directed against Plato himself he pounces upon the argument about the gods and says that Cephalus was wrong in trying to make fear of the gods a deterrent from injustice [Rep. I 330d-331b] and that the argument about divine chastisements is easily discredited and, $<$ as it produces $>$ many distractions and conflicting plausibilities, is an inducement in the opposite direction, being in fact no different from the Bogy and Hobgoblin with which women try to keep little children from mischief. Yet, having thus disparaged Plato's words, in other places again he praises and frequently quotes these lines of Euripides [fr. 991],

In fact there are, though one deride the words,

Zeus and the gods, who mark our mortal woes;

and similarly in the first book concerning Justice he quotes these verses of Hesiod [Op. 242],

Zeus from the heavens inflicted a grievous calamity on them,

Plague and famine at once; and the populace utterly perished, and then says that the gods do these things in order that from the chastisement of the wicked the rest avail themselves of these examples and attempt less such misdeeds [1040A-C; trans. Cherniss, slightly altered].

It must be noticed that "deterrence" and "example" in Plutarch's report are (at least potentially) misleading. As for "deterrence," Cephalus says (in Plato, Rep. I 330d) that "he is to pay the penalty there [=in Hades]

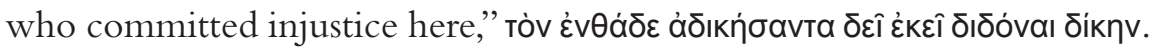
In light of 331a-b, where Cephalus claims that the possession of wealth 
allows one to fulfill one's duties and thus avoid departing to Hades in fear, punishment is there to be taken in the very least as including a retributive element, on the grounds that in Hades one will get what one deserves. In my view, Chrysippus' main focus is in effect on that element: when Chrysippus claims that "the argument about divine chastisements is easily

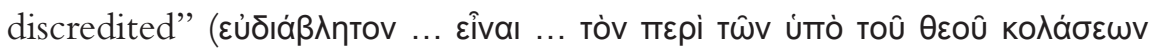
$\lambda$ óyov) I think he is objecting precisely to Cephalus' notion of punishment as payback (the gods cannot be such that they exact penalties from the mortals in those terms, and therefore the stories about Hades are but old wives' tales), whereas when he claims that that argument "produces

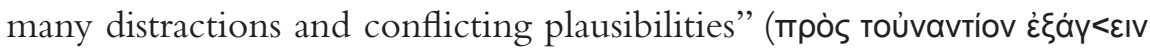

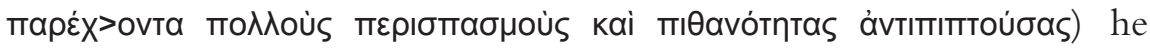
has in mind other issues in the passage such as are raised by Cephalus' assumptions that one may be guilty of failing to perform one's duties even when one is unable to perform them (e.g., when in poverty), and that behavior motivated by mere fear of the gods may be sufficient for one to escape divine punishment (as if the gods did not care about one's virtue or vice). As for "example," on the other hand, Hesiod speaks in vv.23847 about punishment inflicted by Zeus on a mass of people (on account of the transgression of but one), in such a way that punishment cannot be exemplary in the passage (since the whole population is subjected to it). In view of the fact that one is here dealing with the justice of Zeus, Chrysippus' claim must be that everyone who is subjected to punishment by the father of the gods (who, in Stoic terms, is identical to Providence) stands in fact in need of correction (supposedly, for not being a Stoic sage), the one possessed of an overtly wicked nature (v.241: "he who

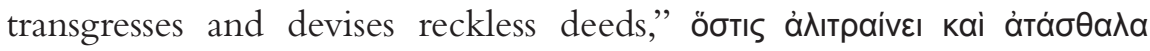
unxaváataı) as well as the rest-who, one is to assume, are seen by Zeus as prone to become such as the other is (since it is implied in the report that they will in due course attempt such misdeeds if not chastised, some of them even if chastised: "in order that ... the rest ... attempt less such

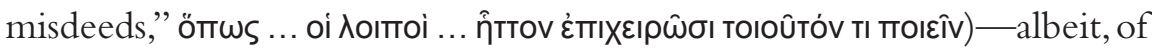
course, punishment and other such therapeutic measures should no more than fit the needs of each person. While a difference between human and divine assessment of one's moral character and dispositions should be stressed (Peleus [see above, pp.19-20] can only appraise Menelaus' nature 
via an assessment of his past deeds, while Zeus knows from the outset whatever one may be up to) the upshot is that, regarding the issue of justice in punishments, for Chrysippus it is only relevant whither one's nature leans one (being the perfect/primary cause of one's inclinations and disinclinations), regardless even of prior offense. ${ }^{10}$

\section{IV}

In conclusion, two further passages should be taken into account:

(i) Cicero, Fat. 7-11

The above understanding of what it means for something to be up to us (according to which it is immaterial whether one's nature is but the result of preceding causes, since one's being of such and such nature suffices for one to stand in need of such and such correction) may be adumbrated in the following passage from Cicero's De Fato:

Non enim, si alii ad alia propensiores sunt propter causas naturalis et antecedentis, idcirco etiam nostrarum voluntatum atque adpetitionum sunt causae naturales et antecedentes. Nam nihil esset in nostra potestate, si ita se res haberet. Nunc vero fatemur, acuti hebetesne, valentes inbecilline simus, non esse id in nobis ... Ut enim et ingeniosi et tardi ita nascantur antecedentibus causis itemque valentes et inbecilli, non sequitur tamen, ut etiam sedere eos et ambulare et rem agere aliquam principalibus causis definitum et constitutum sit.

It is not the case that, if different people are more inclined to different things because of natural antecedent causes, there are also for that reason natural and antecedent causes of our wills and desires. For if that were how the matter stood, nothing would be in our power. As it is, however, we assert that it is not up to us whether we are sharp or dull-witted, strong or weak ... Granted that the talented and the slow are born like that from antecedent causes, and similarly the strong and the weak, still it does not follow that their sitting and walking and doing anything is also defined and decided by primary causes [Fat. 9; trans. Sharples, slightly altered]. 
Cicero here asserts in propria persona that nothing can be up to us if there are antecedent causes of our wills and desires. His own view, as I take it, is that although there are antecedent causes of our dispositions (and our dispositions are thus not up to us) the antecedent causes of our dispositions are not the antecedent causes of our having this or other will and desire (it being therefore open for us to will and desire thus or otherwise in the circumstances, as the examples of Stilpo and Socrates overcoming their respective natures illustrate in the sequence: cf. \$10). The view he criticizes (i.e., Chrysippus' view: cf. 57 ) asserts that there are indeed antecedent causes of our dispositions, and that our dispositions are, in turn, the perfect/primary causes of our having this and not other will and desire in the circumstances $^{11}$ (which, one is to assume, is nevertheless up to us, according to this view) - in such a way that, we may finally see, Chrysippus' reply to the objection in $\$ 40$ is apt to counter not only an argument framed in terms of preceding causes understood as factors which induce one's "impulses" (as the push, and also both visum $(\$ 42)$ and visum obiectum $(\$ 43)$ may seem to imply in the analogy) but also an argument framed in terms of preceding causes understood as factors which shape one's nature.

(ii) Gellius, NAVII $2^{12}$

The account offered above is compatible with (even if not directly derivable from) Gellius, NAVII $2^{13}$. There, an objection is advanced against Chrysippus' theory of Fate which relies upon the thesis that if everything takes place by Fate our actions are not to be attributed to us (presumably because they would not be authored by us), which would in turn render punishment (and even indignation) unfair (\$5). Chrysippus' reply (\$\$7-10) consists in grounding fair penalty on the fact that one is to act thus rather than otherwise in the circumstances, while the fact that one's nature has been fashioned thus rather than otherwise by preceding causes in the form of nature or even education is not even taken into account. ${ }^{14}$

There follows the analogy of the cylinder $(\$ 11)$, in which the "state"15 or "disposition" (Latin ita ... habet, presumably reminiscent of Greek mi்s

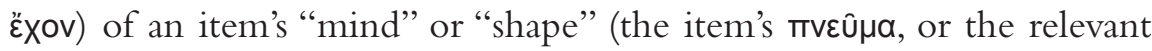
part thereof) accounts for, and therefore grounds one's control over, the outcome in the circumstances: because of the disposition of its shape the cylinder "thereupon [i.e., upon being thrown over a slope] rolls 
downwards," mox ... praeceps voluitur. Gellius then quotes and paraphrases what appears to be Chrysippus' conclusion (\$\$12-14):

Infert deinde verba haec, his quae dixi congruentia:

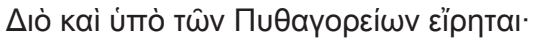

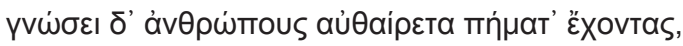

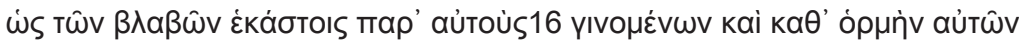

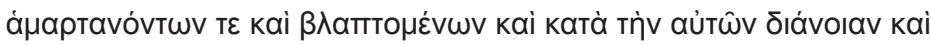
$<\delta ı \dot{\alpha}>\theta \varepsilon \sigma \mid{ }^{17}{ }^{17}$

Propterea negat oportere ferri audique homines aut nequam aut ignavos et nocentes et audaces, qui, cum in culpa et maleficio revincti sunt, perfugiunt ad fati necessitatem, tamquam in aliquod fani asylum et, quae pessime fecerunt, ea non suae temeritate, sed fato esse attribuenda dicunt. Primus autem hoc sapientissimus ille et antiquissimus poetarum dixit hisce versibus,

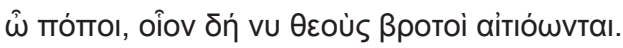

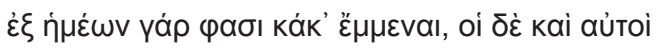

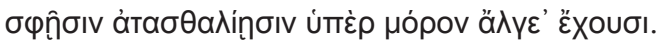

Then he [=Chrysippus] adduces the following words, which are congruous with what I just said:

"Therefore it is said by the Pythagoreans,

You will learn that men's penalties are self-chosen, much to the effect that each one's harms depend on one to take place, and that it is according to one's impulse that one errs and is harmed, as well as according to one's mind and state."

For this reason he denies that one should endure, and listen to, men who are either worthless, idle, harmful, or rash, who, when bound fast in crime and evildoing, seek refuge in the necessity of Fate as in the asylum of a shrine and say that their wicked actions are to be attributed not to their recklessness but to Fate. But the first to say this was the wisest and oldest of the poets in these verses [a 32-4],

Oh for shame, how the mortals accuse us gods, for they say evils come from us, when it is they, rather, who by their own recklessness win sorrow beyond what is due!

The use of mapá + acc. and of a 32-4 has a close parallel in Diogenianus' report (cf. Eus., Praep. Ev. VI 8 2)-which points in the direction of a 
continuity between Diogenianus' and Gellius' respective reports (see above, pp.109-111, 117-118). Also, it is capital to appreciate the role played by

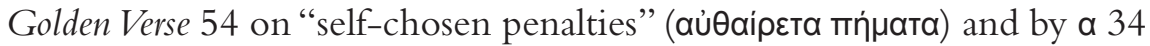
on men who "by their own recklessness win sorrow beyond what is due"

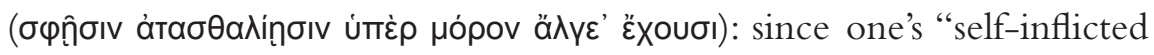
penalties" appear to be the harm (cf. Tûv $\beta \lambda \alpha \beta \hat{\omega} v$ and $\beta \lambda \alpha \pi т \mu_{\mu} \varepsilon \dot{v} \omega v$ in $\$ 12$ ) one causes oneself in doing wrong, and since the use of a 34 implies such

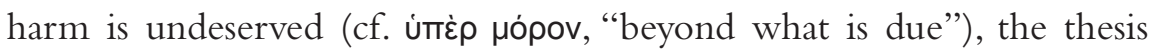
asserted by Chrysippus in the passage appears to be that one is harmed (or rather harms oneself) beyond desert when one does wrong-a thesis which is attributed to him in the following testimony:

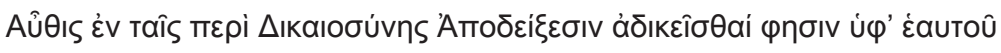

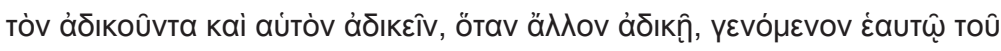

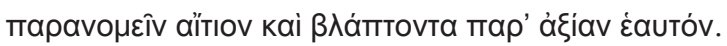

Later in the Demonstrations concerning Justice he [=Chrysippus] says the wrongdoer is wronged by herself and wrongs herself whenever she wrongs another, for she has become a cause of transgression for herself and is harming herself beyond desert [Plutarch, St. Rep. 16 1041C; trans. Cherniss, slightly altered].

If one also bears in mind that (according to Aristotle, EE IV/EN $V$ 1132b15-17) the Pythagoreans define justice (tò סíkaıv) as reciprocity

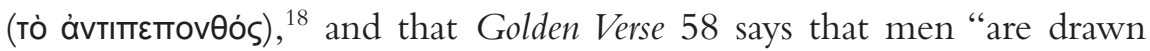
from one place to the other like cylinders, with limitless penalties" ( $\dot{\omega} \varsigma$...

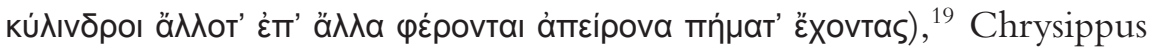
appears to derive from his reply to the objection concerning justice in honor and punishments an amendment to Pythagorean doctrine: to harm oneself "according to one's own mind and state" (кaтò tịv aủTûv ठıávoıav

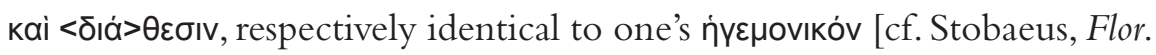
II 65,2-3; Plutarch, VM 3 441c] and to the stable state or disposition

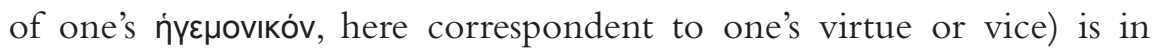
effect to have evil inflicted by oneself upon oneself through one's own perversity - but, contrary to Pythagorean thought, that cannot even be just, much less what justice is: since being vicious and doing wrong are (the only) evil, while being wronged is a mere dispreferred indifferent, no commensurability is possible between the two; moreover, since one 
is said by the Pythagoreans to be drawn like a cylinder in being vicious and doing wrong (which, in light of Chrysippus' cylinder analogy, is to be understood as a claim to the effect that being vicious and doing wrong is but one's nature), one cannot be said to be the ultimate origin of one's dispositions - and therefore, since the only evils are the ones suffered by the wrongdoers themselves (who accordingly stand in need of correction for being such), justice cannot but consist, as suggested, in making use of whichever means are apposite in order to mend one's ways.

\section{Appendix}

Gellius, NAVII 2 5-11

[5] "Si Chrysippus," inquiunt, "fato putat omnia moueri et regi nec declinari transcendique posse agmina fati et uolumina, peccata quoque hominum et delicta non suscensenda neque inducenda sunt ipsis uoluntatibusque eorum, sed necessitati cuidam et instantiae, quae oritur ex fato," omnium quae sit rerum domina et arbitra, per quam necesse sit fieri, quicquid futurum est; et propterea nocentium poenas legibus inique constitutas, si homines ad maleficia non sponte ueniunt, sed fato trahuntur. [6] Contra ea Chrysippus tenuiter multa et argute disserit; sed omnium fere, quae super ea re scripsit, huiuscemodi sententia est. [7] "Quamquam ita sit," inquit, "ut ratione quadam necessaria et principali coacta atque conexa sint fato omnia, ingenia tamen ipsa mentium nostrarum proinde sunt fato obnoxia, ut proprietas eorum est ipsa et qualitas. [8] Nam si sunt per naturam primitus salubriter utiliterque ficta, omnem illam uim, quae de fato extrinsecus ingruit, inoffensius tractabiliusque transmittunt. Sin uero sunt aspera et inscita et rudia nullisque artium bonarum adminiculis fulta, etiamsi paruo siue nullo fatalis incommodi conflictu urgeantur, sua tamen scaeuitate et uoluntario impetu in assidua delicta et in errores se ruunt. [9] Idque ipsum ut ea ratione fiat, naturalis illa et necessaria rerum consequentia efficit, quae fatum uocatur. [10] Est enim genere ipso quasi fatale et consequens, ut mala ingenia peccatis et erroribus non uacent." [11] Huius deinde fere rei exemplo non hercle nimis alieno neque inlepido utitur. "Sicut," inquit, "lapidem cylindrum si per spatia terrae 
prona atque derupta iacias, causam quidem ei et initium praecipitantiae feceris, mox tamen ille praeceps uoluitur, non quia tu id iam facis, sed quoniam ita sese modus eius et formae uolubilitas habet: sic ordo et ratio et necessitas fati genera ipsa et principia causarum mouet, impetus uero consiliorum mentiumque nostrarum actionesque ipsas uoluntas cuiusque propria et animorum ingenia moderantur."

[5] "If Chrysippus," they say,"believes that all things are moved and ruled by Fate, and that the paths and coils of Fate cannot be bent or transgressed, then the sins and faults of men, too, should not cause indignation, nor be attributed to themselves and their wills but to a certain necessity and urgency which arises from Fate," which is the mistress and arbiter of all things, <and $>$ through which it is necessary that everything take place which will take place; and therefore the penalties for criminals have been unfairly established by law, if men do not come to evil voluntarily, but are dragged by Fate. [6] Against this Chrysippus says many things subtly and acutely, but the meaning of almost everything he wrote on the topic is of the following kind. [7] "Although it is true," he says, "that all things are united and connected by a necessary and primary reason which is Fate, yet the states of our minds are themselves subject to Fate to the extent that this is their characteristic quality. [8] For if they have been fashioned in a healthy and beneficial manner by nature, they will transmit in a most inoffensive and tractable manner all that force which falls upon them from without on account of Fate. But if they are rough, ignorant, rude, and without any support from education, then, even if they are urged by the strike of slight or null fated inconvenience, by their own perversity and voluntary impulse they plunge into continuous faults and mistakes. [9] And that this much should take place in this way is due to that natural and necessary arrangement of things which is called Fate. [10] For it is by the type itself fated, so to speak, and arranged that evil states should not be without sins and mistakes." [11] He then uses an illustration of approximately this point which, by Hercules!, is not altogether alien or lacking in wit. "As," he says, "if you throw a cylindrical stone over a sloping, steep piece of ground, you will indeed have made for the cause and the onset of its tumbling down, yet it thereupon rolls downwards, this time not because you make it so, but because such is the disposition of its shape and the roll-ability of its form; just so the order, reason, and 
necessity of Fate sets in motion the types themselves and the beginnings of causes, but the impulses of our designs and thoughts, and our actions themselves, are regulated by our own will and the states of our minds."

${ }^{1}$ I would like to thank everyone with whom I discussed a previous version of this paper in April 2013 at a meeting of the Projeto Temático FAPESP "Filosofia Grega Clássica" (directed by Marco Zingano) at the University of São Paulo, especially David Sedley (Christ's College, Cambridge).

${ }^{2}$ The following paragraphs sum up and develop a few points from my "Is Diogenianus (apud Eus., Praep. Ev.VI 8) a Source for Chrysippus' Reply to the Idle Argument?” Dissertatio 36 (2012): 343-64.

${ }^{3}$ Bobzien (1998a: 283-5) points out what she terms a "one-sided, causative concept of depen-

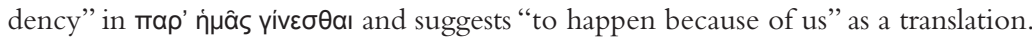

${ }^{4}$ As O'Keefe (2005) points out. Whether Epicurus intended such reading is, however, a question I remain silent about. See Sedley (1983); Bobzien (2000 and 2006).

${ }^{5}$ Which entails causal transitivity: "And if 'impulses' do [have an antecedent cause], so too do those things which follow on 'impulse, and therefore so too do assents," et, si adpetitus, illa etiam, quae adpetitum sequuntur, ergo etiam adsensiones - presumably, if "impulse" has an antecedent cause, then that which has "impulse" as its antecedent cause (namely, assent) has itself the antecedent cause of "impulse" as its antecedent cause.

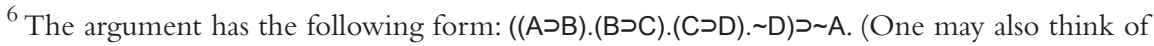
substituting Chrysippean (strict) implication for Philonian (material) implication.)

${ }^{7}$ See my "Is Diogenianus ...," p.357 n.9.

${ }^{8}$ As Bobzien herself (1998a: 290-301) acknowledges.

${ }^{9}$ The example is the same as the one attributed to Zeno in Arius Didymus, Epit. Phys. fr. 18 Diels = Stobaeus, Flor. I 13 138,14-22 (LS 55A), where it is said that ppóvnбı ("wisdom") is the cause of to ppoveiv ("being wise"), and that it is impossible that the cause be present and that of which it is the cause not be the case. Such being Zeno's notion of a cause (i.e., what is later termed a perfect cause), it is perfectly acceptable that in Cicero the perfect cause should be called primary (i.e., a cause in the primary sense).

${ }^{10}$ Gellius, NA XIV 4 relates that philosophers of more delicate doctrines (delicatiorum quidam disciplinarum philosophi) found Chrysippus' praise of Justice (uerba ipsa Chrysippi de Iustitia scripta) in Book I of his work On the Fine and Pleasure to be the image not of Justice but of Cruelty (Saenitiae imaginem istam esse, non Iustitiae).

11 Here I depart from, e.g., Sedley (1993), according to whom the passage attributes to Chrysippus the view that the antecedent causes of our dispositions are the primary causes of our wills and desires.

doispontos, Curitiba, São Carlos, vol. 10, n. 2, p.109-134, outubro, 2013 
${ }^{12}$ The following paragraphs should correct the excesses in my "Is Diogenianus ...," pp.360-3.

${ }^{13}$ Text and translation of Gellius, NA VII 2 5-11 may be found in the Appendix.

14 "The strike of slight or null fated inconvenience" (paruus sive nullus fatalis incommodi conflictus, \$8) evidently points to factors which induce one’s presentations; "all that force which falls upon them from without on account of Fate" (omnis illa vis quae de fato extrinsecus ingruit, ibid.) may refer either to factors which induce one's presentations or to factors which shape one's nature.

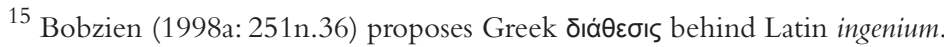

${ }^{16}$ Following Hertz-Hosius (1903), who print aủroùs (MS U [Urbinas 309]), not aủтoîs- the latter probably being a contamination from غ́кáotoıs.

${ }^{17}$ Usener's conjecture.

${ }^{18}$ Following Jackson (1879), ad loc.

${ }^{19}$ Possibly, the source of Chrysippus' cylinder a analogy.

\section{Bibliography}

BOBZIEN, S. 1998a. Determinism and Freedom in Stoic Philosophy.

Oxford.

. 1998b. Chrysippus'Theory of Causes, in: IERODIAKONOU, K.

(ed.) Topics in Stoic Philosophy. Oxford, pp.196-242.

2000. Did Epicurus Discover the Free Will Problem? Oxford Studies in Ancient Philosophy 19, 287-338.

2006. Moral Responsibility and Moral Development in Epicurus'

Philosophy, in: REIS, B. (ed.) The Virtuous Life in Greek Ethics.

Cambridge, pp.206-29.

CHERNISS, H. 1976. Plutarch: Moralia, vol. XIII. 2 parts. Cambridge, Mass.

De LACY, P.H. 2005. Galen: On the Doctrines of Hippocrates and Plato. First Part: Books I-V.3rd ed. Berlin.

DIELS, H.1879. Doxographi Graeci. Berlin.

FREDE, M. 1980. The Original Notion of Cause, in: SCHOFIELD, M.; 
BURNYEAT, M.F.; BARNES, J. (eds.) Doubt and Dogmatism: Studies in Hellenistic Epistemology. Oxford, pp.217-49. (Reprinted in: FREDE, M. 1987. Essays in Ancient Philosophy. Minneapolis, pp.125-50.)

HAHM, D.E. 1994. Self-Motion in Stoic Philosophy, in: GILL, M.-L. \& LENNOX, J.G. (eds.) Self-Motion: From Aristotle to Newton. Princeton, 1994, pp.175-225.

HERTZ, M.J. \& HOSIUS, C. 1903. A. Gellii Noctium Atticarum Libri XX. 2 vols. Leipzig.

JACKSON, H. 1879. The Fifth Book of the Nicomachean Ethics of Aristotle. Cambridge.

LAURSEN, S. 1995. The Early Parts of Epicurus, On Nature, 25th Book, Cronache Ercolanesi 25, pp. 5-109. 1997. The Later Parts of Epicurus, On Nature, 25th Book, Cronache Ercolanesi 27, pp. 5-82.

LONG, A.A. \& SEDLEY, D.N. 1987. The Hellenistic Philosophers. 2 vols. Cambridge.

O'KEEFE, T. 2005. Epicurus on Freedom. Cambridge.

SEDLEY, D.N. 1983. Epicurus' Refutation of Determinism, in:VV.AA.

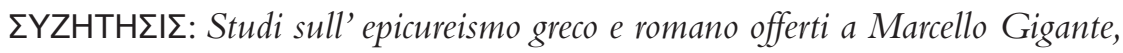
vol. I. Napoli, pp.11-51.

1993. Chrysippus on Psychophysical Causality, in:

BRUNSCHWIG, J. \& NUSSBAUM, M.C. (eds.) Passions and Perceptions: Studies in Hellenistic Philosophy of Mind. Cambridge pp.313-31.

SHARPLES, R.W. 1991. Cicero: On Fate \& Boethius: The Consolation of Philosophy IV.5-7,V. Warminster.

WACHSMUTH, K. \& HENSE, O. 1884-1923. Ioannis Stobaei Anthologium. 5 vols. with an appendix. Weidmann. 